CATALLAXY

Volume 4 Issue 1 June 2019

e-ISSN 2544-090X

$\triangle$ www.catallaxy.pl

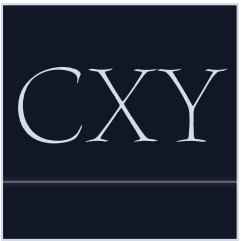

Oryginalny artykut naukowy

otrzymano: 07.06.2019 / zaakceptowano: 28.06.2019 / opublikowano online: 30.06 .2019

Zalewski, M. (2019). Zróżnicowanie metod zarządzania projektami informatycznymi jako źródło przewag konkurencyjnych. Catallax 4(1): 57-72. doi:10.24136/cxy:2019.002.

\title{
Zróżnicowanie metod zarządzania projektami informatycznymi jako źródło przewag konkurencyjnych
}

\author{
MARCIN ZALEWSKI \\ Uniwersytet Ekonomiczny we Wroctawiu, Wydziat Nauk Ekonomicznych, ul. Komandorska 118/120, 53-345 Wroctaw, \\ Polska \\ వ pikador94@gmail.com \\ (iD) orcid.org/0000-0001-6467-0407
}

\begin{abstract}
Abstrakt
Motywacja: Motywacją do podjęcia tematu była chęć zwrócenie uwagi na mankamenty oraz walory poszczególnych koncepcji, w szczególności grupy metodyk zwinnych oraz tradycyjnych dla projektów informatycznych.

Cel: Głównym celem jest wykazanie statystycznej opłacalności migracji do metodyk lepiej dopasowanych w przypadku branży adaptacyjnej, w jakiej operują przedsiębiorstwa wytwarzające oprogramowanie. Celem szczegółowym jest wykazanie pozytywnych zależności, w przypadku prawidłowego doboru koncepcji zarządzania do oczekiwań klienta oraz zespolu projektowego.

Materiały i metody: Wnioski opracowano na podstawie analizy porównawczej grupy metodyk, a także przez weryfikację badań przeprowadzonych przez przedsiębiorstwo Scott Ambler + Associates.

Wyniki: W konkluzji stwierdzono przede wszystkim, że nie ujmując tradycyjnemu podejściu do zarządzania, nie wpisuje się ono do kanonu nowoczesnych i adaptacyjnych technik, które sprostałyby wymaganiom stawianym w dobie globalizacji przez elastyczne projekty informatyczne. Ponadto, na podstawie analizy odpowiedzi respondentów, można dostrzec, jak drastycznie zmiana podejścia do całego cyklu projektowego wpływa na prawdopodobieństwo sukcesu oraz niweluje nieporozumienia na linii klient-wykonawca.
\end{abstract}

Stowa kluczowe: przewagi konkurencyjne; metodyki zarządzania; zarządzanie ryzykiem JEL: F66; M15; O22

\section{Wprowadzenie}

Rosnąca rola wyboru systemu zarządzania projektami $\mathrm{w}$ przedsiębiorstwach prowadzi coraz częściej do trudnych decyzji, których efekt może być atutem lub problemem danego przedsiębiorstwa. Specyfika nowych projektów sprawia, że poszukuje się kolejnych wskazówek, które mają pomóc w wyborze odpowiedniej metodyki i nie tylko zapewnić przewage konkurencyjną na tle innowacyjnego systemu zarządzania, ale także zapewnić stabilniejszy i obarczony mniejszym ryzykiem cykl produkcji. Tematyka zarządzania staje się bardziej istotna przez zmieniające się wymagania klientów co do usług i produktów. Do skomplikowania procesu produkcji doprowadziła rosnąca dynamika projektów, a także zwiększenie udziału projektów opartych na tworzeniu oprogramowania oraz szeroko pojętej innowacyjności. Zmiany te skutkowały 
nie tylko wyodrębnieniem nowej grupy osób odpowiedzialnych za kontrolę nad płynnym przebiegiem projektu. Sprowokowały również do wielu badań i analiz, których wyniki potwierdzają złożoność, jak i benefity płynące $z$ inwestycji czasowej i materialnej w ten czynnik przez dane przedsiębiorstwo. Sama idea różnicowania sposobu i metod, jakich przestrzega się $\mathrm{w}$ czasie pracy, jest interesująca $z$ uwagi na jej stale rosnącą rolę oraz zbieżność $z$ potencjalnie wyższym prawdopodobieństwem osiągnięcia sukcesu projektu.

Celem artykułu jest próba zebrania argumentów za i przeciw zmianom sposobu, $\mathrm{w}$ jaki podejmuje się wyzwanie sprostania kolejnym projektom. Poruszona jest również statystyczna opłacalność podjęcia ryzyka i wyboru nowych metod projektowych, które mają realny wpływ na konkurencyjność przedsiębiorstwa. Badania, na których opiera się podstawowa część artykułu, przeprowadzono przede wszystkim na przełomie 2013 i 2014 roku, na grupie 173 przedsiębiorstw, które operowały w branży informatycznej, a dokładniej w grupie przedsiębiorstw zajmujących się wytwarzaniem oprogramowania.

W sekcji 2. dokonano przeglądu literatury przedmiotu. W sekcji 3. przedstawiono istotę i genezę zarządzania projektami. W sekcji 4. scharakteryzowano współczesne metody zarządzania projektami. W sekcji 5. opisano wykorzystane materiały i metody. W sekcji 6. dokonano analizy porównawczej zwinnych i tradycyjnych założeń projektowych. W sekcji 7. przedstawiono otrzymane wyniki. W sekcji 8. zawarto podsumowanie przeprowadzonej analizy.

\section{Przegląd literatury}

Obecnie, zarządzanie projektami stanowi efekt wieloletnich prób sprostania wymaganiom, jakie stawiały największe wyzwania XX wieku. Począwszy od realizacji projektów wojskowych, kosmicznych i cywilnych, starano się przez lata wypracować spójny, zorganizowany i stabilny proces dążenia do założonych celów. Nauka na błędach i praktyka poparta kolejnymi, tak bardzo zróżnicowanymi przed- sięwzięciami, pozwoliły wykształcić zasady prowadzenia wieloosobowych i złożonych działań, z możliwie silną neutralizacją ryzyka i usuwaniem ograniczeń.

\section{Istota i geneza zarządzania projektami}

Pojęcie zarządzania projektami można zdefiniować jako grupę czynności, które kierownik, sponsor oraz uczestnicy projektu wykonują w celu osiągnięcia głównych i pośrednich celów, w zaplanowanym czasie i o określonym budżecie (Pawlak, 2006, ss. 17-22). Dynamiczny rozwój, wysoka użyteczność i skuteczność takiego sposobu planowania $\mathrm{w}$ globalizującej się światowej gospodarce sprawiły jednak, że zarządzanie projektami wykorzystywane jest nie tylko w przypadku złożonych, wieloletnich projektów. Coraz częściej stosuje się je w celu realizacji planów w pracy, nauce, sporcie, administracji, kulturze czy działalności gospodarczej. Tak wysokie zapotrzebowanie na alternatywne sposoby zarządzania projektami, ze względu na ich specyfikę, rodzi z kolei popyt na wiedzę, jej ciągłą aktualizację i przystosowanie do warunków, w jakich muszą się odnaleźć obecnie przedsiębiorstwa (Kolm, 2019). Jednym $z$ podstawowych motywatorów w zakresie zarządzania jest utrzymanie przewagi konkurencyjnej. Wiąże się ona nierozerwalnie $z$ takimi aspektami projektu, jak: zarządzanie jego przebiegiem, organizacją i dojrzałością projektową, a także wsparciem informatycznym i minimalizowaniem ryzyka. Tak szeroki wachlarz wymagań i potrzeba kontroli wielu czynników w czasie realizacji projektu, doprowadziły $z$ kolei do wykształcenia się wielu metodyk znajdujących swoje zastosowanie $\mathrm{w}$ przedsiębiorstwach informatycznych. Zarządzanie przedsięwzięciami rozpoczęło się od wykształcenia na przełomie lat 50. i 60. metod sieciowych polegających na identyfikacji krytycznych zadań w projekcie, których ukończenie mogło znacznie wpłynąć na terminowość realizacji. Metody sieciowe używane były przede wszystkim $\mathrm{w}$ zastosowaniach cywilnych, a do najpopularniejszych z nich można zaliczyć Program evaluation and review technique (PERT) oraz 
Critical path method (CPM) (Oliński, 2016, ss. 7-9). Metody te opierały się na analizie ścieżki krytycznej, czyli grupie najbardziej newralgicznych zadań oraz na programowaniu sieciowym. Rozwój tych oraz siostrzanych metod trwał nieprzerwanie przez kolejne 30 lat, zdobywając sprzymierzeńców i uznanie, nawet wśród sympatyków tradycyjnych metod zarządzania. Spowolnienie prac nastąpiło dopiero po napotkaniu bariery w postaci ograniczeń technologicznych. Jednak stagnacja nie potrwała długo, $z$ uwagi na popularyzację komputerów wydajnych pod koniec lat 80. XX wieku. Przełom ten stanowił kolejny kamień milowy w zarządzaniu projektami, pozwalając na opracowanie najistotniejszych programów z tej dziedziny. Wśród najważniejszych czynników modelujących współczesne techniki zarządzania projektami można wymienić (Pawlak, 2006, ss. 13-17):

- postęp technologiczny umożliwiający tworzenie tańszych ofert $\mathrm{w}$ krótszym czasie, a także ułatwienie komunikacji między uczestnikami projektu dzięki sieci Internet;

- zastąpienie dużych, trudnych w opanowaniu jednostek przez małe zespoły pozwalające na większą elastyczność i samodzielność;

- potrzeba stworzenia przewagi konkurencyjnej, która wymaga większej elastyczności przedsiębiorstwa, ciągłych usprawnień oraz czujności w stosunku do rynkowych konkurentów;

- konieczność zwiększania jakości oferowanych produktów, którą można osiągnąć dzięki różnicowaniu metod pracy i jak najefektywniejszemu wykorzystaniu posiadanych zasobów;

- globalizacja oraz związany z nią rozwój sieci komputerowych pozwalający na niemal natychmiastowy kontakt między zespołami, przedsiębiorstwami i poszczególnymi grupami zainteresowań, co umożliwia transfer wiedzy i możliwość łączenia zasobów, niezależnie od położenia geograficznego;

- zapotrzebowanie na pracowników wykazujących większe zróżnicowanie umiejęt- ności, co przyczynia się do lepszej alokacji na stanowiskach pracy i daje możliwość ograniczenia liczby pracowników, a co za tym idzie - zmniejszenia cyklicznych kosztów przedsiębiorstwa.

Pomijając wygodę, lepsze wyniki finansowe oraz możliwość dorównania konkurencji wynikające $z$ zastosowania nowoczesnych metod zarządzania, innym argumentem była również niemożność prowadzenia dużych projektów zgodnie z tradycyjnymi metodami, które z czasem okazały się zbyt ograniczone, jak na obecne wymagania przedsiębiorstw. Proces ten wykształcił samodzielną dziedzinę zarządzania, której przedstawicieli i jednocześnie ekspertów nazywa się kierownikami projektu (project manager, PM). Rosnąca znaczenie tych specjalistów jest szczególnie pożądane przede wszystkim wśród przedsiębiorstw działających w otoczeniu globalnym. Przy czym, otoczenie globalne można rozumieć zarówno w kontekście konkurencji międzynarodowej na rynku lokalnym, jak i w ramach zdobywania klientów międzynarodowych. Poszukiwanie nowych przewag wiąże się z pozyskiwaniem wiedzy, implementacją nowych rozwiązań, jak i zatrudnieniem personelu będącego $w$ stanie wykorzystać potencjał płynący $z$ modernizacji procesu zarządzania w przedsiębiorstwie.

Osiągnięcie określonej pozycji konkurencyjnej wiąże się z kolei z nieustanym badaniem rynku, w obrębie którego działa przedsiębiorstwo oraz poszukiwaniem uwarunkowań mogących poprawić zdolność do budowania przewag konkurencyjnych. Konkurencyjność jest procesem, którego uczestnicy rywalizują w drodze do osiągnięcia analogicznych celów (Stankiewicz, 1999, s. 18). Celem konkurencyjności jest zbudowanie, a następnie utrzymanie, przewagi konkurencyjnej, którą można utożsamiać $z$ preferowanym przez klienta wyborem oferty danego przedsiębiorstwa lub powstaniem wartości dodanej, którą przedsiębiorstwo jest w stanie wypracować dla swoich klientów (Glabiszewski, 2004, s. 15). Tworzenie i utrzymywanie przewag wiąże się nierozerwalnie $z$ zyskami finansowymi, które wpływają do przedsiębiorstwa dzięki 
efektom osiągniętym za pomocą przewagi konkurencyjnej.

$\mathrm{Na}$ schemacie 1. i schemacie 2. przedstawiono cykle zwinnych oraz tradycyjnych technik zarządzania. W przypadku metodyk zwinnych, każdy cykl (iteracja) polega na dostarczeniu kolejnej porcji funkcjonalności. Natomiast w przypadku metodyki Waterfall, cykl jest liniowy i przewidywalny, a wszystkie funkcjonalności zostają dostarczone zbiorczo, zgodnie ze szczegółowym harmonogramem. Największym mankamentem tradycyjnego podejścia jest trudność weryfikacji postępów przed dotarciem do końcowej fazy projektu, a także niemożność wprowadzenia jakichkolwiek zmian. Przedsiębiorstwo działające na szybko rozwijającym się rynku, będzie musiało podjąć ryzyko ewentualnych modernizacji, jeżeli $w$ trakcie jego działania zmieniły się wymagania rynkowe. $Z$ kolei metodyka zwinna, pozwala na dostosowanie i kształtowanie projektu przy każdej iteracji, jednak może to prowadzić do drastycznego zwiększania kosztów lub ostatecznie ukończenia mniejszej ilości funkcjonalności w początkowo zakładanym okresie.

\section{Współczesne metody zarządzania projektami}

Chcąc wyróżnić najczęściej wykorzystywane w ostatnich latach metody zarządzania, należy wymienić podejście zwinne - Agile project management oraz podejście klasyczne, reprezentowane najczęściej przez metodykę projects in controlled environments 2 (PRINCE2) i project management body of knowledge (PMBoK). Podejście tradycyjne jest odzwierciedleniem metodologii realizowanej w cyklu sekwencyjnym, w przypadku której uwagę skupiono na procesy liniowe, szczegółową dokumentację oraz planowanie, w którego skład wchodzi prioretyzowanie obowiązków. Druga grupa z przedstawionego podziału, czyli metody nowoczesne, to $z$ kolei skupiona na dostarczeniu wysokiej jakości produktu forma współpracy między wyspecjalizowanymi zespołami. Cechy, na których skupia się metoda nowoczesna to przede wszystkim: chęć ciągłego doskonalenia wykorzystywanych praktyk, bieżąca kontrola oraz elastyczne struktury organizacyjne. Popularność tych trzech stylów kierowania można zauważyć przede wszystkim na rynku projektów naukowo-badawczych, projektów informatycznych oraz w szeroko pojętej branży odpowiedzialnej za generowanie innowacji.

Adaptacyjne zarządzanie projektami to podejście sprowadzające się do wykorzystania grupy metodyk określanych jak0 elastyczne (zwinne), ścisłej współpracy z klientem oraz kreowania stosunkowo luźnych ram projektowych. Oznacza to, że projekt w trakcie realizacji jest dostosowywany przez obie strony, a jego strukturę można przedstawić za pomocą iteracji, czyli odpowiednio podzielonego na funkcjonalności zakresu. Podstawą zwinnego zarządzania projektami jest więc otwartość na zmieniające się wymagania klienta, szybka ich adaptacja, a także brak wyodrębnionej fazy projektowej, która stanowi etap tradycyjnego zarządzania (Lyngso, 2014, ss. 96-99). Dynamiczne otoczenie w projektach może być jednak wyzwaniem dla całego zespołu, $z$ uwagi na krótkoterminowe planowanie i konieczność skupienia się na powierzonym zadaniu, mimo ciągłego modelowania jego specyfikacji. W tym podejściu, zespoły stanowią małe grupy (kilku lub kilkunastoosobowe), których pracę nadzoruje kierownik pełniący rolę mentora. Pracownicy powinni charakteryzować się efektywnością, elastycznością i umiejętnością kooperacji na wysokim poziomie, $z$ uwagi na częstą potrzebę bezpośredniego kontaktu. Istotą takiej współpracy powinno być osiągnięcie satysfakcji klienta, dzięki okresowemu dostarczeniu kolejnych wersji działającego produktu, którego podstawową miarą będzie szybkość wytwarzania oraz jego stabilność i działanie. Zwinne zarządzanie projektami wyróżnia przede wszystkim prostota - zespoły $\mathrm{w}$ projekcie są samozarządzalne, a kontrolę nad wymaganiami wspomaga fakt bliskiej współpracy między sferą biznesu i wykonawcami. Przy takiej strategii działania, pracownicy nie mają problemów z późnymi zmianami w specyfika- 
cji, które w przypadku tradycyjnych metod, mogłyby mieć destrukcyjny wpływ. Atutem jest również odejście od standaryzacji, co oznacza mniejszą ilość dokumentów, większy indywidualizm zespołu oraz możliwość rozpoczęcia pracy bez znajomości całego zakresu wymaganych prac. Taka forma adaptacyjnego zarządzania jest odpowiednia dla małych oraz średnich przedsiębiorstw, których celem jest niezbyt rozbudowany produkt. Cel końcowy powinien być jasno określony przez zleceniodawcę, jednak spełnienie wspomnianych wymagań pozwala na większą swobodę oraz lepsze dopasanie do projektów określanych jako innowacyjne (Lachiewicz i Matejuna, 2007, ss. 148-151). Podstawą do interpretacji zwinnego podejścia jest $z$ kolei manifest Agile, czyli dokument spisany w 2001 roku przez reprezentantów innowacyjnych metod tworzenia oprogramowania, których celem było stworzenie alternatywy dla tradycyjnego modelu kaskadowego. Manifest, jak i cała metoda, były przeznaczone przede wszystkim dla branży wytwarzającej oprogramowanie $\mathrm{i}$, mimo częściowego przenikania $\mathrm{w}$ inne obszary zarządzania projektami, jest on dedykowany dla rozwiązań informatycznych.

PRINCE2 to $z$ kolei metodyka opracowana $w$ latach 80 . XX wieku. Standard ten został stworzony przez rząd brytyjski z przeznaczeniem na użycie $\mathrm{w}$ środowisku informacji technologicznej (information technology, IT), natomiast numer 2 został dodany do metodyki PRINCE w 1996 roku, kiedy założenia przeszły gruntowną modernizację (Hedeman i Seegers, 2009, ss. 1-7). Ta metodologia zarządzania projektami została oparta na kaskadowości, czyli wykonywaniu kolejnych, podstawowych czynności, jedna po drugiej, jako odrębnych faz projektu. Każda z następujących po sobie czynności jest więc jednym etapem, kolejnym elementem kaskady. Efektem wykorzystania tej metody powinny być jasno i szczegółowo określone obowiązki oraz rzetelnie i dokładnie przeprowadzone planowanie, które stanowi jeden z najważniejszych kroków silnie rzutujący na pozostałe etapy projektu. Planowanie jest procesem, w którym osoby odpowiedzialne za cały projekt powinny: określić ograniczenia, na jakie można trafić, przeprowadzić analizę kosztów oraz ekonomicznie uzasadnić działania zespołu. PRINCE2 jest obecnie jedną $z$ najpopularniejszych metodologii zarządzania projektami na świecie, jednak nie oznacza to, że stanowi rozwiązanie uniwersalne i dopasowane do potrzeb każdego projektu. Decydując się na ten standard należy pamiętać, że jest on przeznaczony przede wszystkim do przewidywalnych projektów, które od początku mają sztywno określone ramy, odnośnie tego komu, kiedy, i w jaki sposób dostarcza się efekt pracy (Hedeman i Seegers, 2009, ss. 7-23).

PMBoK to druga $z$ wymienionych, klasycznych metod zarządzania projektami. Składa się ona z grupy rozwiązań i standardów przedstawionych przez członków Project Management Institute. Standard PMBoK Guide jest zbiorem powszechnych praktyk, które zostały zatwierdzone przez American National Standards Institute i stanowią narodowe normy zarządzania projektami. Zgodnie z PMBoK, zarządzanie ma procesowy charakter, który determinuje swoją budowę, a działania zarządcze można interpretować właśnie jako wspomniane procesy. Każdy projekt można podzielić na pięć faz, którymi kolejno są: inicjowanie, planowanie, wykonanie, zakończenie oraz ostatnia faza obejmująca monitorowanie i kontrolę (Project Management Institute, 2013, ss. 15-18). Struktura ta nie jest jednak jedyną, ponieważ dotyczy tylko podziału ze względu na cykl projektowy, natomiast wszystkie czterdzieści siedem procesów występujących w metodyce, można również zawęzić do dziesięciu grup ze względu na obszary wiedzy (Project Management Institute, 2013, ss. 5-7). Mnogość procesów nie oznacza jednak, że w każdym projekcie należy wykorzystania każdy z nich. Zgodnie PMBoK Guide, powinno się dostosować ich wykorzystanie do realizowanego projektu, użytych narzędzi oraz technik, a także skupić się na spełnieniu wymagań stawianych przez otoczenie. Wiedzę na temat całego procesu można czerpać z sześciu opublikowanych dotychczas wersji PMBoK, z których najnowsza datowana jest na 2017 rok. Ostatecz- 
nie, stosowanie PMBoK Guide można uznać za pomyślne tylko $\mathrm{w}$ przypadku dostarczenia produktu zgodnego $z$ uprzednio ustalonymi wymaganiami (Koszlajda, 2010, ss. 66-68).

Zaletą każdej $z$ tych metod jest przede wszystkim ich specyficzne przeznaczenie oraz możliwość adaptacji. Potencjalne przedsiębiorstwo ma do wyboru nie tylko metodykę, która najlepiej będzie odpowiadała na potrzeby prowadzonego projektu, ale również możliwość jej modyfikacji. Mnogość rozwiązań, procesów i standardów pozwala na pominięcie zbędnych elementów i standaryzację procesu pracy, w sposób dający najwięcej korzyści. Głównym beneficjentem tych rozwiązań jest ostatecznie klient, do którego przedsiębiorstwo jest się $\mathrm{w}$ stanie dopasować i skrócić do minimum czas potrzebny na adaptację i wdrożenie wybranej metodologii w zaplanowanej formie.

\section{Materiały i metody}

Próbę przyporządkowania klientowi odpowiedniej metody zarządzania nad projektem będącym rezultatem nadchodzącej współpracy należy podjąć na bazie wielu zależnych od siebie czynników. Jako podstawową, wykorzystano ilościową metodę sondażu diagnostycznego, która dzięki przeprowadzonemu przez przedsiębiorstwo Scott Ambler + Associates ankietowaniu, stanowiła główne, poddane analizie źródło. Zastosowano również analizę porównawczą obu grup metodyk zarządzania projektami, opartą o literaturę przedmiotu.

\section{Analiza porównawcza zwinnych i tradycyjnych założeń projektowych}

Grupa tradycyjnych metodyk zarządzania wiąże się $z$ zaplanowaniem wszystkich kroków, jakie należy podjąć do osiągnięcia celu, bazując na kaskadowej i sekwencyjnej strukturze planowania. W tym podejściu zakłada się, że klient jest pewny oczekiwanego rezultatu i zdaje sobie sprawę ze wszystkich, postawionych wymagań. Harmonogram pracy w takim projekcie będzie zatem przejrzysty i czytelny, a umowa zostanie sformalizowana i pozbawiona wątpliwości co do sposobu działania. Dzięki ściśle określonym regułom i zdyscyplinowanym sposobie pracy, minimalizowane jest ryzyko i można szybciej skompletować zespół, który nie musi być tak wysoce kompetentny, jak w przypadku zespołów metodyk zwinnych. Wybór ten jednak ogranicza możliwość wprowadzania zmian $\mathrm{w}$ trakcie trwania projektu oraz utrudnia koncentrację na faktycznych oczekiwaniach klienta (Kopczyński, 2014, ss. 6-11). Natomiast metodyki zwinne, dają znacznie większą swobodę w przypadku dynamicznie wprowadzanych zmian i elastycznego zarządzania projektem. Oznacza to, że działając na rynku, gdzie dużą rolę odgrywa innowacyjność, przedsiębiorstwo będzie w stanie znacznie szybciej dążyć do stworzenia przewagi konkurencyjnej, dzięki szybkiej adaptacji nowych rozwiązań, obecnych w otoczeniu.

W tabeli 1. przedstawiono zestaw podstawowych parametrów, według których przeprowadzono porównanie metodyki zwinnej oraz klasycznej. Porównując oba podejścia można zauważyć, że różnice obejmują praktycznie wszystkie etapy wykonania projektu, poczynając od przygotowania po jego zakonczenie. W tych dwóch przypadkach różni się nawet definicja sukcesu, którą w tradycyjnym podejściu było sprostanie wszystkim założeniom i zgodność z założonym planem, natomiast $\mathrm{w}$ podejściu Agile sukces utożsamiany jest bezpośrednio ze zdolnością adaptacji do warunków w projekcie, które zmieniają się w czasie jego trwania. Metodyki zwinne charakteryzuje również odmienne zorientowanie na cel, ponieważ przedsiębiorstwo zobligowane jest do koncentracji na dostarczaniu kolejnych funkcjonalności oraz zorientowaniu na interesariuszy. W przypadku podejścia tradycyjnego, uwaga skupiona jest na procesie samym $\mathrm{w}$ sobie i podziale zadań, a także na procedurach i narzędziach wspomagających realizację i kontrolę.

Podsumowując przedstawione porównanie podejścia zwinnego oraz tradycyjnego można stwierdzić, że oba rozwiązania stanowią odpowiedź na zróżnicowane potrzeby 
klientów. Jednak wybór każdego z nich wiąże się $z$ nastawieniem na specyficzną ścieżkę współpracy, która może w dużym stopniu wpłynąć na ostateczny kształt finalnego produktu.

\section{Wyniki badania}

Skalę zjawiska, jakim jest wyjątkowo szybki rozwój $w$ segmencie zwinnych metodyk zarządzania projektami, można zauważyć analizując dane zaprezentowane na wykresie 1., opracowane przez International Data Corporation (IDC), będące jednym $z$ wiodących dostawców informacji rynkowych. IDC oszacowało sumę przychodów przypadających na przedsiębiorstwa operujące na rynku narzędzi wykorzystywanych do zwinnych metodyk zarządzania. Zakres czasowy obejmował lata 2013-2017. Podstawowym wnioskiem jest wyjątkowo szybki wzrost przychodów w całym okresie, który wynosił średnio ponad $30 \%$. Tak znaczace tempo i podwojenie wyników w tym segmencie w ciągu zaledwie 3 lat, świadczy nie tyle o spadku zainteresowania tradycyjnymi metodami zarządzania, co o przekonaniu się wielu przedsiębiorstw o potrzebie zmiany, ze względu na charakter prowadzonych projektów (Harvard Business School Publishing, 2016, ss. 4-7). Przedsiębiorstwa decydują się zatem na uzupełnienie wiedzy przez szkolenia, kursy czy zatrudnienie trenerów. Pomagają oni wdrożyć poszczególne ceremonie, nawiązać poprawną komunikację $z$ klientem oraz wprowadzają w świat narzędzi niezbędnych lub znacznie ułatwiających pracę $w$ iteracyjnym procesie.

O efektach zmiany sposobu zarządzania projektowego można dowiedzieć się z przeprowadzonych badań przez przedsiębiorstwo Scott Ambler + Associates wśród 173 podmiotów wytwarzających oprogramowanie. Pierwszym z pytań, które zadano każdemu z nich, była ocena efektywności zespołów projektowych pracujących w ramach poszczególnych metodyk (wykres 2.).

Badane przedsiębiorstwa oceniały kolejno z perspektywy czasu to, czy dany projekt był sukcesem, stanowil wyzwanie dla pracowni- ków i osób zarządzających projektem, czy też projekt upadł i oczekiwany produkt nie został dostarczony. Badania dotyczyły pięciu metod zarządzania wśród których znalazły się: Agile, Lean, Ad-Hoc, metody tradycyjne i iteracyjne. Koncepcja Lean Software Development oraz zarządzanie Ad-Hoc wykorzystano w analizie $z$ uwagi na ich przynależność do kanonu nowoczesnych metod zarządzania, jak i chęci uwzględnienia całości badań ankietowych, przeprowadzonych przez przedsiębiorstwo Scott Ambler + Associates. Kryterium kwalifikującym projekt do grupy, która odniosła sukces było dostarczenie produktu końcowego do klienta i spełnienie wyznaczonych przez niego kryteriów. Wyzwanie stanowiły z kolei projekty, które zostały dostarczone, jednak nie spełniały wszystkich wymagań. Przykładem może być projekt, który osiągnął wymaganą jakość, jednak przekroczył limit czasowy lub osiągnął niższy niż planowany wskaźnik rentowności.

Ostatnia grupa to projekty, których ukończenie nie doszło do skutku, jednak nie wyszczególniono bezpośrednich przyczyn porażki grupy projektowej. Wyniki uzyskane $z$ tego badania można podzielić na dwie grupy. Pierwsza stanowiła zbiór zespołów, których ukończone projekty, spełniające wszystkie wymagania, stanowiły przynajmniej $60 \%$. W tej grupie na pierwszym miejscu znalazła się koncepcja Lean, powstała w oparciu o zasady i narzędzia systemu produkcyjnego Toyoty. Koncepcja Lean, identyfikowana najczęściej jako metodyka szczupła, mimo swojej odmienności od zwinnych, również zaliczana jest do grupy nowoczesnych metodyk zarządzania $z$ uwagi na chęć rozwiązania problemów związanych z praktyką zarządzania projektami z ubiegłego stulecia. Do jej najważniejszych cech zalicza się: próby ograniczenia marnotrawstwa, dążenie do ciągłej poprawy jakości, a także wizualizacji procesów.

W dalszej kolejności uplasował się kolejno model przyrostowy oraz metodyka Agile, które charakteryzuje iteracyjny cykl i okresowe dostarczanie kolejnych funkcjonalności. We wszystkich trzech podejściach odsetek projektów, które nie odniosły sukcesu 
nie przekraczał 10\%, jednak w metodyce Agile odsetek ten był najmniejszy. Do drugiej grupy z bardzo zbliżonymi wynikami, można zaliczyć model Ad-Hoc oraz tradycyjne podejście projektowe. W grupie tej, projekty zakończone sukcesem stanowiły mniej więcej $50 \%$ projektów ogółem. Ponad 30\% projektów przyjęto $z$ zastrzeżeniami, natomiast aż $12-15 \%$ stanowily nieukończone lub przerwane realizacje. W przypadku projektów prowadzonych Ad-Hoc, niska skuteczność może wynikać z braku wyspecjalizowanej kadry i samodzielności grupy eksperckiej. W takim projekcie, menedżer odpowiada za całą realizację, jednak nie ma pełnej kontroli nad wszystkimi pracownikami. Podejście tradycyjne charakteryzowało się z kolei najniższą skutecznością z wymienionych grup, jednak niekoniecznie wynikało to bezpośrednio $z$ winy osób zajmujących się tworzeniem oprogramowania czy kierownictwa projektu. Żyjąc w erze globalizacji i e-gospodarki można zauważyć, w jak szybkim tempie zmieniają się wymagania klientów oraz jak zyskuje na znaczeniu umiejętność adaptacji do trendów, zmian i nowopowstających czynników rynkowych. Podejście tradycyjne staje się zatem coraz mniej przydatne, szczególnie w nawiązaniu do wspomnianej e-gospodarki, w której wymagania w stosunku do wytwarzanego oprogramowania ulegaja stałym zmianom. Długotrwałe projekty są w takim środowisku obarczone znacznie większym ryzykiem i ustępują miejsca metodykom uwzględniającym zmienność specyfikacji w czasie (Pawlak, 2006, ss. 13-17). Oprócz stale kształtowanych wymagań technicznych, pojawiających się nowych technologii i kreowanej potrzeby innowacyjności, zmieniają się również oczekiwania i wymagania klienta, które prowadzące badanie przedsiębiorstwo również zawarło w swoim raporcie.

Nawiązując do problemów związanych $z$ zastosowaniem podejścia tradycyjnego oraz słabych wyników osiągniętych w przytoczonym badaniu, można założyć, że początkowy wybór metodyki zarządzania był nieodpowiednio dostosowany do realizowanego projektu. Kwestia wyboru i dopasowania sposobu pracy stanowi obecnie jeden $z$ podstawowych problemów, z uwagi na trudność uwzględnienia specyfiki projektu (Pietras i Szmit, 2003, ss. 60-62). Rozbudowanie i stopień zaawansowania metodyki nie może przekraczać możliwości organizacji, a sam proces rozwijania oprogramowania lub nietechnicznego produktu, nie powinien być wyzwaniem od strony systemowej (Sadowski i Zajdel, 2009, ss. 273-276). Na niekorzyść przedsiębiorstw, w erze globalizacji działają również nowe obszary ryzyka i pojawiają się nieprzewidywalne czynniki. Niechęć do metodyk zwinnych może z kolei budzić rosnąca liczba wymagań co do efektywności projektów, minimalizacji kosztów czy twardych ram czasowych i finansowych. Ostatecznie przedsiębiorstwa stoją przed wyborem ograniczonego rozwiązania liniowego lub rozwiązań zwinnych, jednak coraz częściej pojawiają się hybrydy czerpiące $z$ obu podejść, starające się wpasować $w$ wąskie gardło specjalistycznych branży.

$\mathrm{Na}$ wykresie 3. przedstawiono sposób, w jaki klient identyfikuje ukończenie projektu sukcesem oraz warunki, jakie przedsiębiorstwo powinno spełnić, aby projekt mógł być zaliczony do udanych. 58\% ankietowanych postrzegało ukończenie projektu na czas jako jeden $z$ najważniejszych czynników. Potwierdza to rolę, jaką odgrywa terminowość na rynku, gdzie przewage konkurencyjną buduje się dzięki szybkim i zdecydowanym reakcjom na nadarzające się okazje. Znacznie mniej osób (36\%) uważało, że koniecznym warunkiem pozytywnie zakończonego zlecenia jest jego wykonanie bez przekraczania planowanego budżetu. Czynnik ten może być istotny przede wszystkim dla przedsięwzięć, których możliwość refinansowania wiąże się $z$ kolejnymi opóźnieniami lub nawet przerwaniem projektu. $14 \%$ respondentów zwróciło uwagę na wykonanie zlecenia zgodnie ze specyfikacją ustaloną $\mathrm{w}$ fazie planowania. Tak niski odsetek pozytywnych odpowiedzi wśród pytanych o ten aspekt świadczył o świadomości klientów, którzy zdają sobie sprawę z elastyczności tworzonych rozwiązań i częstej konieczności wprowadzania zmian czy nawet modyfikacji funkcjonalności, jako kompromisu budżetowego lub czasowego. Ostatecz- 
nie, jedynie $8 \%$ respondentów utożsamiało sukces projektu ze spełnieniem wszystkich trzech składowych, a co czwarty z nich zaliczał do tej grupy projekty będące zarówno ukończonymi na czas, jak i w określonym budżecie. $\mathrm{W}$ przytoczonym badaniu istotna wydaje się szybkość, z jaką można rozpocząć współpracę i przejść przez cały jej proces. Czas jest również jednym $z$ kwantyfikowalnych oraz obiektywnych czynników, który w warunkach gospodarki opartej na wiedzy, stanowi jedno $z$ głównych źródeł przewag konkurencyjnych. W przypadku zarządzania zespołami, można przewidzieć potencjalny okres, potrzebny na integrację między przedsiębiorstwami oraz oszacować, jak wybrana metodyka wpłynie na długość trwania projektu. Wykorzystywanie przez wykonawcę skomplikowanej i czasochłonnej pod względem implementacji metody zarządzania, może zniechęcić klientów chcących zlecić drobne projekty, ponieważ koszt szkoleń, przekazu wiedzy i praktykowania specyficznych procesów i ceremonii, przekroczy ich zasoby finansowe. Takiej sytuacji można zapobiec przez odpowiednie dopasowanie metody zarządzania do realiów konsumenckich i wybór metody popularnej w danej branży. Zastosowanie znanego systemu pozwoli przede wszystkim na wzrost zaufania do przedsiębiorców, którzy mieli okazję z sukcesem przeprowadzić projekt $\mathrm{w}$ danej metodyce i wynieśli know-how wystarczające do znacznie szybszego uruchomienia kolejnego projektu.

$\mathrm{Na}$ wykresie 4. zawarto porównanie pięciu modeli pod względem jakości produktu, wartości dla interesariuszy, wskaźnika rentowności oraz ram czasowych. Każda kategoria została oceniona przez respondentów w skali od -10 do 10 punktów, gdzie maksymalny wynik oznaczał bardzo wysoką efektywność, minimalny jej odwrotność. Natomiast im wynik był bliższy zeru, tym bardziej neutralny wpływ miał dany bodziec w danej koncepcji. Pierwszy czynnik, czyli jakość produktu, określa skuteczność zespołów programistycznych na bazie doświadczeń użytkowych w dostarczonym systemie. W tym zestawieniu przodowała koncepcja Lean, jednak metodyka Agile oraz metody iteracyjne odbiegały od niej tylko o jedną jednostkę na przedstawionej skali i wahały się między 3.8, a 4.2 punktu. Znacznie większą różnicę $\mathrm{w}$ jakości dostarczonego produktu oferowały metodyki tradycyjne, jednak tylko zarządzanie typu Ad-Hoc zyskało negatywną opinię (punkty ujemne). Powodem osiągnięcia tak niskiego poziomu jakości, mogło być przede wszystkim nieprzestrzeganie przez grupę deweloperów określonego rozkładu i zorganizowanego procesu. Na niekorzyść działał również niższy poziom kontroli oraz przecenienie znajomości projektu przez pracowników, kończące się często zaniżoną jakością wykonania.

Ocena kolejnego czynnika (wartość dla interesariuszy) była bardziej pozytywna w przypadku wszystkich metodyk. Celem badania była ocena umiejętności dostarczenia rozwiązania, które spełni faktycznie potrzeby zleceniodawcy. Dużą rolę odgrywało więc doświadczenie i świadomość wymagań w ciągu całego procesu. Ostateczny efekt tego badania zawiera tylko pozytywne średnie, jednak na podium $z$ wyjątkowo wysokim wynikiem powyżej 5 punktów, plasowała się jedynie koncepcja Lean i metody iteracyjne. Wysoki rezultat $\mathrm{w}$ obu przypadkach można uzasadnić stałym kontaktem $z$ klientem oraz kontrolą postępów prac. W tych metodykach, istotny aspekt stanowi określenie wartości dla klienta, a następnie trzymanie się ustalonych założeń. Osiągnięte wyniki często są więc zbieżne z oczekiwanym przez klienta finalnym produktem.

Kolejnym czynnikiem poddanym analizie był wskaźnik zwrotu $z$ inwestycji (return on investment, ROI). Badane osoby zobligowane były do opisania, na bazie własnych doświadczeń, efektywność wskaźnika rentowności. Po raz kolejny wysoko oceniono metody iteracyjne - Lean oraz Agile. Podejście tradycyjne oraz Ad-Hoc uzyskały z kolei wynik bardzo zbliżony do neutralnego, co może oznaczać, że inwestycje te nie były ani znacznie przecenione, ani niedocenione $\mathrm{w}$ kwestii opłacalności.

Ostatnim analizowanym obszarem była terminowość i stopień zgodności z wstępnie określonymi ramami czasowymi projektu. 
Znacznie częściej ukończone na czas lub niezbyt wydłużone projekty zarządzane były po raz kolejny przez grupę metodyk zwinnych. Pierwsze miejsce w rankingu uzyskała koncepcja Lean osiągając średnią na poziomie 6 punktów. Na końcu zestawienia, z niezbyt zadowalającym wynikiem, powyżej -1 punktu, znalazła się z kolei metoda tradycyjna. Brak odpowiedniej koordynacji nie przysłużył się również $\mathrm{w}$ przypadku zarządzania metodą Ad-Hoc, gdzie skala praktycznie zrównała się z zerem.

Podsumowując można wyciągnąć wniosek, że strategie zwinne, iteracyjne, a także koncepcja Lean znacznie przewyższały pozostałe metodyki, brane pod uwage $\mathrm{w}$ badaniu. Analizując wyniki, można zauważyć bardzo zbliżone noty $w$ przypadku skuteczności podejścia iteracyjnego oraz Agile. Brak statystycznej różnicy odnotowano również $\mathrm{w}$ odniesieniu do metody tradycyjnej oraz podejścia Ad-Hoc. Na korzyść i wiarygodność zebranych danych wpływa z kolei fakt, że definicja sukcesu nie była narzucona przez autorów badania, lecz pozostawiona osobom, które miały bezpośrednią styczność $z$ danym projektem i były $\mathrm{w}$ stanie zdefiniować ich spójność z oczekiwaniami. Takie podejście do zadawanych pytań sprawiało, że uzyskane odpowiedzi nie odnosiły się do wyników mierzonych „surową" skalą, a do realnych oczekiwań zleceniodawców.

\section{Zakończenie}

$\mathrm{Na}$ podstawie przeprowadzonej analizy porównawczej metodyk zwinnych oraz klasycznych, jak i analizy badań zrealizowanych przez przedsiębiorstwo Scott Ambler + Associates, można scharakteryzować okoliczności, w jakich dane przedsiębiorstwo powinno wykorzystać podejście zwinne, a kiedy pozostać lub powrócić do klasycznych metod. Jednym z kluczowych czynników w procesie wyboru jest wielkość projektu. Metodyka Agile od początku przeznaczona była dla małych zespołów projektowych i podejście zwinne nie będzie dobrym wyborem w przypadku wielkoformatowych przedsięwzięć. Wielkość projektu odgrywa więc kluczową rolę w początkowym wyborze. Kolejny istotny czynnik, na który trzeba zwrócić uwagę, to czas potrzebny na wdrożenie systemu. W przypadku metodyki klasycznej, okres ten wynosi 6-12 miesięcy, natomiast $w$ metodyce zwinnej trwa on $z$ reguły nie więcej niż 2 miesiące. Metoda dłuższa w procesie wdrożenia oraz rozmiar projektu, plasują podejście tradycyjne jako najbardziej odpowiednie w projektach badawczych twardych oraz projektach rozwojowych miękkich i twardych.

Kolejny czynnik decydujący o wyborze to rodzaj projektu. Agile, dzięki odmiennemu podejściu, stanowi świetne narzędzie do pracy przede wszystkim przy projektach innowacyjnych, o charakterze upowszechniającym i testującym. Agile znajdzie również zastosowanie w przypadku projektów badawczych miękkich, których obszar skupia się na badaniach naukowych (Lachiewicz i Matejuna, 2007, ss. 147-149). Metodyki zwinne migrują przede wszystkim w kierunku podejścia adaptacyjnego zamiast predykcyjnego, a możliwość częstej zmiany wymagań jest czymś naturalnym. Istotne jest również zorientowanie na ludzi zamiast na procesy, co było domeną podejścia tradycyjnego. Twórczy styl pracy ekspertów $\mathrm{w}$ danej dziedzinie, a także wciągnięcie kulturowych osobliwości i zachowań do kanonu cech metodyk projektowych, staje się nie tyle ryzykowną niewiadomą, co atutem i potencjalnym zasobem, gotowym do wykorzystania.

Ostatecznie, zbudowanie i utrzymanie przewagi konkurencyjnej, w kontekście metodyki prowadzenia projektu, będzie się opierało na poszukiwaniu i użyciu rozwiązania optymalnego dla danego projektu. Często odpowiednim wyborem będzie wykorzystanie mocnych stron kilku sprawdzonych praktyk, zktórych przedsiębiorstwo będzie w stanie wyodrębnić najbardziej użyteczne narzędzia, zamiast ślepo podążać za aktualnymi trendami. Nie można jednak negować rosnącego zainteresowania zwinnymi metodykami i większego współczynnika sukcesu w projektach, które na nich polegały. Można uznać, że porzucenie tradycyjnych metod zarządzania projektami, szczególnie w przypadku branży zajmującej się 
rozwojem oprogramowania, jest statystycznie znacznie bardziej opłacalne niż obstawanie przy nich $z$ uwagi na znajomość i doświadczenie. Metodyki zwinne okazały się więc odpowiedzią na kształtujące się przez ostatnie lata wymagania współczesnych przedsiębiorstw i wypełniają niszę dla projektów nastawionych na ciągłe zmiany i modelowanie tworzonego produktu. Przedsiębiorstwa szukające przewag konkurencyjnych w obszarze innowacji procesowych, mogą próbować nowych rozwiązań, które pozwolą na zwiększenie zadowolenia klientów oraz obniżenie kosztów zarządzania projektami, czyli produkcji. Na korzyść „odważnych” przedsiębiorców dążących do migracji w kierunku nowych sposobów zarządzania, działa również rosnąca rola innowacji, a także rozwoju technologicznego. Akumulacja i wdrażanie nowych zasobów pozwala budować przewagę $\mathrm{w}$ dziedzinie innowacyjności. Ostatecznie bardzo wyraźnie kształtuje się nowy trend, zwany zamiennie metodykami elastycznymi, zwinnymi, bądź adaptacyjnymi, podyktowany potrzebami projektów informatycznych. Samo istnienie nowego rodzaju wzorców prowadzenia projektów w zarządzaniu jest więc odpowiedzią na niski odsetek projektów ukończonych z powodzeniem (Kopczyński, 2014, s. 102) oraz próbą technologicznej adaptacji w czasach globalizacji. Dokładniejsza analiza wpływu poszczególnych metodyk $z$ grupy zwinnych koncepcji zarządzania na wzrost przewagi konkurencyjnej wymagałaby poświęcenia większej uwagi na wyróżniających je cechach i metodykach najbardziej zyskujących na popularności.

\section{Bibliografia}

Dorette, J. (2011). Comparing Agile XP and Waterfall software development processes in two start-up companies. Nieopublikowana praca magisterska. Chalmers University of Technology, Szwecja.

Glabiszewski, W. (2004). Kształtowanie konkurencyjności przedsiębiorstwa. Ekonomika i Organizacja Przedsiębiorstwa, 4.
Harvard Business School Publishing. (2016). Agile practice: the competitive advantage for a digital age. Pobrane 17.04.2019 z: https://hbr.org.

Hedeman, B., i Seegers, R. (2009). PRINCE2 2009 edition: a pocket guide. Pobrane 17.04.2019 z https://vanharen.net.

Kolm, A. (2019). Geneza $i$ istota zarządzania projektami. Pobrane 17.04.2019 z http://zarzadzanieprojektami.it.

Kopczyński, T. (2014). Rola i kompetencje kierownika projektu $\mathrm{w}$ zwinnym zarządzaniu projektami na tle tradycyjnego podejścia do zarządzania projektami. Studia Oeconomica Posnaniensia, 2(9).

Koszlajda, A. (2010). Zarządzanie projektami IT: przewodnik po metodykach. Gliwice: Helion.

Lachiewicz, S., i Matejuna, M. (2007). Problemy wspótczesnej praktyki zarządzania, tom 1. Łódź: Politechnika Łódzka.

Lyngso, S. (2014). Agile strategy management: techniques for continuous alignment and improvement. Boca Raton: CRC Press.

Łabuda, W. (2015). Podejście zwinne a tradycyjne do projektów wytwarzania oprogramowania. Zeszyty Naukowe Warszawskiej Wyższej Szkoty Informatyki, 13. doi:10.26348/znwwsi.13.57.

Mariani, M., i Mattix, T. (2013). Scale agile throughout the enterprise: a PwC point of view. Pobrane 17.04.2019 z https://docplayer.net.

Oliński, M. (2016). Zarządzanie projektami. Olsztyn: Uniwersytet Warmińsko-Mazurski w Olsztynie.

Pawlak, M. (2006). Zarządzanie projektami. Warszawa: PWN.

Paymo Academy. (2018). Project management methods, methodologies, and frameworks: a guide for beginners. Pobrane 17.04.2019 z https://www. paymoapp.com.

Pietras, P., i Szmit, M. (2003). Zarzadzanie projektem: wybrane metody i techniki. Łódź: Horyzont.

Project Management Institute. (2013). A guide to the project management body of knowledge. Pobrane 17.04.2019 $\mathrm{z}$ http://dinus.ac.id.

Sadowski, A., i Zajdel, M. (2009). Podejście systemowe w naukach o zarządzaniu. Studia Prawno-Ekonomiczne, 80.

Scott Ambler + Associates. (2013). IT project success rates: survey results. Pobrane 17.04.2019 $z$ http://www.ambysoft.com.

Stankiewicz, M. (1999). Budowanie potencjału konkurencyjności przedsiębiorstwa. Toruń: TNOiK. 
Informacje uzupetniające

Wkład autorski: autor zaakceptował ostateczną wersję artykułu.
Źródła finansowania: artykuł został w całości sfinansowany ze środków własnych autora.

Uwagi: wyniki badania były zaprezentowane na 9. Ogólnopolskiej Konferencji Naukowej Problemy gospodarkiświatowej (10 maja 2019, Toruń). 
Aneks

Tabela 1.

Porównanie zwinnych i klasycznych metod zarządzania projektami

\begin{tabular}{|c|c|c|}
\hline Parametry & Podejście zwinne & Podejście klasyczne \\
\hline wymagania projektowe & $\begin{array}{c}\text { produkt jest odkrywany etapami, a wymaga- } \\
\text { nia definiowane w trakcie jego trwania }\end{array}$ & $\begin{array}{l}\text { wymagania określone w początkowej fazie } \\
\text { trwania projektu lub przed jego rozpoczeciem }\end{array}$ \\
\hline $\begin{array}{l}\text { odpowiedzialność } \\
\text { za produkt }\end{array}$ & product owner jako jedyny właściciel produktu & $\begin{array}{l}\text { rozkład odpowiedzialności między menadże- } \\
\text { ra projektu i produktu oraz marketera }\end{array}$ \\
\hline rola menadżera & $\begin{array}{c}\text { Osoba ściśle współpracująca z zespołem } \\
\text { i będąca jego członkiem }\end{array}$ & $\begin{array}{c}\text { menadżer działa niezależnie od zespołów } \\
\text { deweloperskich }\end{array}$ \\
\hline cykl zarządzania & $\begin{array}{l}\text { dostarczanie kolejnych funkcjonalności } \\
\text { w każdej iteracji }\end{array}$ & $\begin{array}{l}\text { liniowy i przewidywalny cykl oraz dostarcza- } \\
\text { nie funkcjonalności określonych w szczegóło- } \\
\text { wym harmonogramie }\end{array}$ \\
\hline przykładowe metody & $\begin{array}{c}\text { Lean, Scrum, Extreme Programming, Feature } \\
\text { Driven Development }\end{array}$ & PMBOK, PRINCE2, Waterfall \\
\hline długość cykli & $\begin{array}{c}\text { krótkie i adaptacyjne cykle modelowane przez } \\
\text { zmienne warunku }\end{array}$ & $\begin{array}{c}\text { długie, z góry zaplanowane, nieelastyczne } \\
\text { cykle }\end{array}$ \\
\hline koszt projektu & $\begin{array}{c}\text { brak znajomości budżetu potrzebnego na cały } \\
\text { projekt, zastąpiony prognozami i szacunkami } \\
\text { na najbliższe etapy }\end{array}$ & $\begin{array}{l}\text { zamknięty i dokładnie oszacowany budżet, } \\
\text { znany najczęściej przed rozpoczęciem prac }\end{array}$ \\
\hline specyfika organizacji & $\begin{array}{c}\text { prosta i szybko przystosowująca się do bieżą- } \\
\text { cych potrzeb struktura organizacji pracy }\end{array}$ & $\begin{array}{c}\text { sformalizowana i ściśle sprecyzowana forma } \\
\text { oraz organizacja pracy }\end{array}$ \\
\hline zarządzanie ryzykiem & $\begin{array}{l}\text { możliwość wystąpienia ryzyka związanego } \\
\text { z niezaplanowanymi od początku zmianami }\end{array}$ & $\begin{array}{c}\text { bardzo niskie prawdopodobieństwo wystą- } \\
\text { pienia ryzyka }\end{array}$ \\
\hline adaptacja zmian & elastyczne podejście i otwartość na zmiany & $\begin{array}{l}\text { ciężkie do wprowadzenia zmiany, często ogra- } \\
\text { niczone przez skomplikowane procedury }\end{array}$ \\
\hline zespół projektowy & $\begin{array}{c}\text { małe, samoorganizujące się zespoły, które kładą } \\
\text { wysoki nacisk na współpracę i komunikację }\end{array}$ & $\begin{array}{c}\text { wyspecjalizowany i restrykcyjnie prowadzony } \\
\text { zespół o demokratycznym stylu kierowania, } \\
\text { skupiony na harmonogramie i budżecie }\end{array}$ \\
\hline rezultaty & $\begin{array}{l}\text { nieprzewidywalne z uwagi na brak ustalonego, } \\
\text { pełnego planu działań }\end{array}$ & $\begin{array}{l}\text { przewidywalne, możliwe do przedstawienia } \\
\text { w formie liczbowej jako stopień wykonania } \\
\text { w stosunku do całości }\end{array}$ \\
\hline
\end{tabular}

Źródło: Opracowanie własne na podstawie Dorette (2011, ss. 9-14), Łabuda (2015, ss. 58-59), Paymo Academy (2018).

Schemat 1.

\section{Cykl projektu Waterfall}

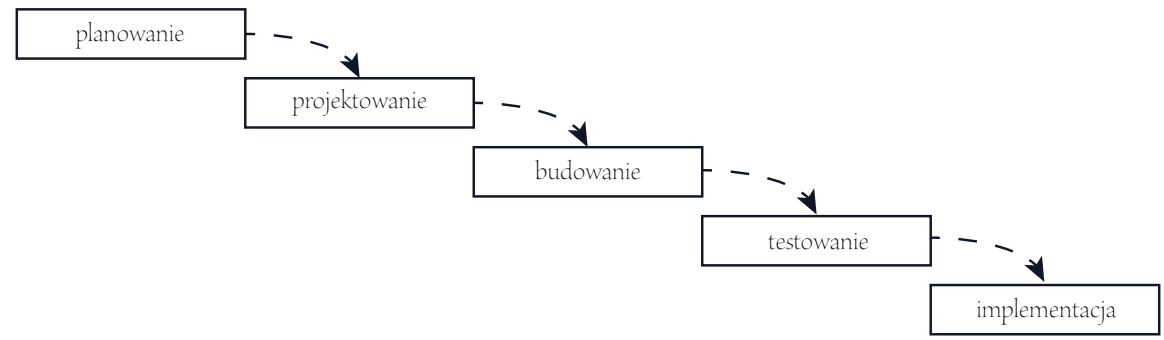

Źródło: Mariani i Mattix (2013). 
Schemat 2.

Iteracyjny cykl projektu Agile

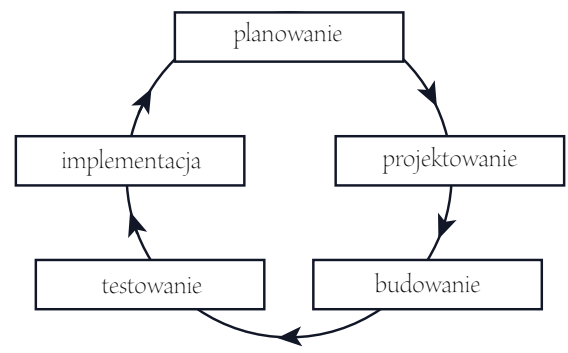

Źródło: Mariani i Mattix (2013).

Wykres 1.

Wielkość rynku narzędzi wykorzystywanych do zarządzania cyklem życia produktu w metodyce Agile w latach 2013-2017 (w mln USD)

1200

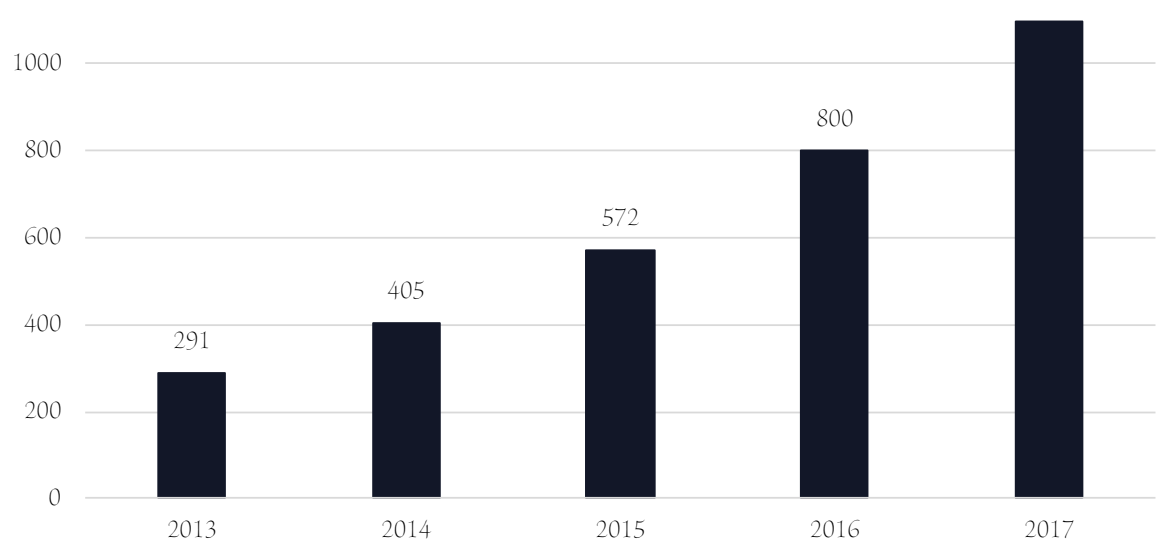

Źródło: Harvard Business School Publishing (2016). 
Wykres 2.

Odsetek projektów zakończonych sukcesem oraz porażką w wybranych metodach zarządzania projektami $(\mathrm{w} \%)$

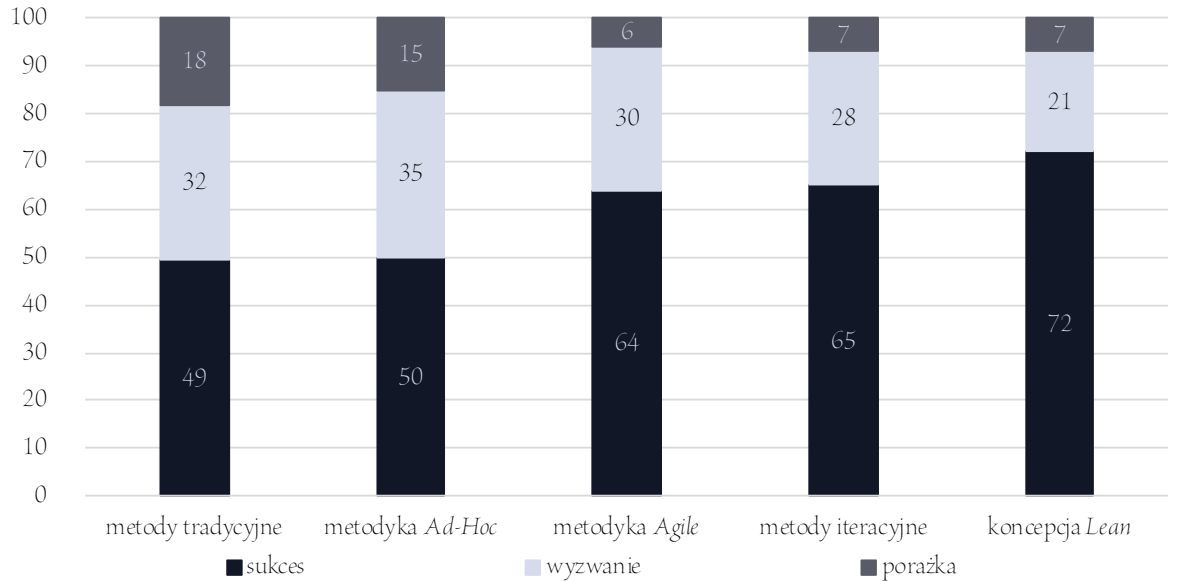

Źródło: Scott Ambler + Associates (2013).

\section{Wykres 3.}

Wybrane wymagania przedsiębiorców definiujące sukces projektu (w \%)

70

60

50

40

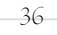

30

20

14

10

8

0
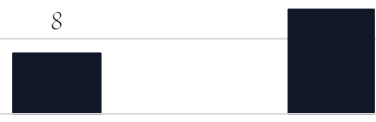

wszystkie trzy wymagania

zgodność ze specyfikacją

zgodność z budżetem

ukończenie na czas

Źródło: Scott Ambler + Associates (2013). 


\title{
Wykres 4.
}

\section{Efektywność czynników projektowych w poszczególnych podejściach do zarządzania projektem}

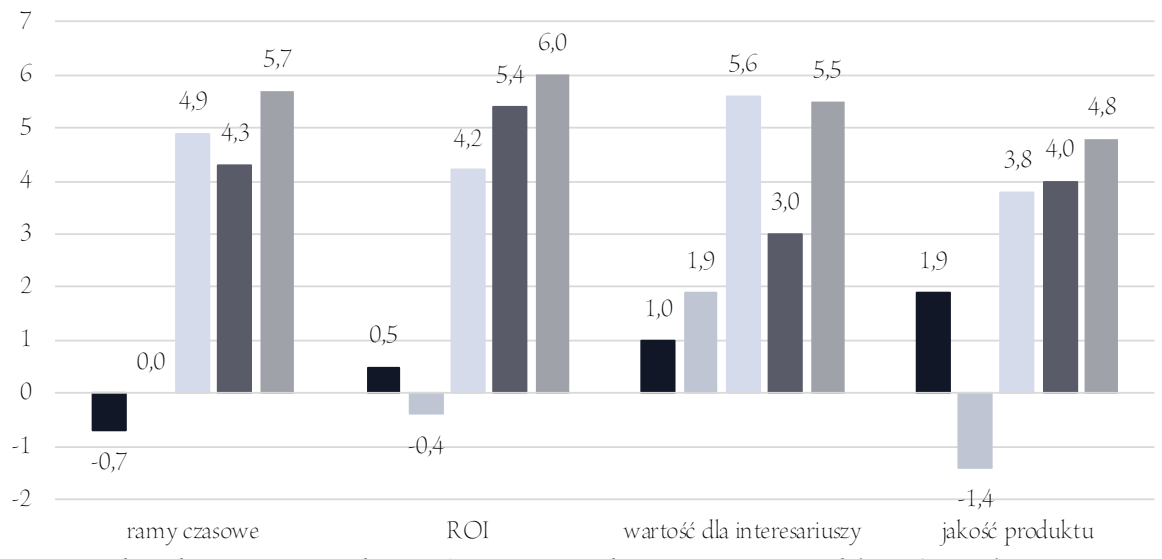

metody tradycyjne zarządzanie Ad-Hoc

metody iteracyjne metodyka Agile koncepcja Lean

Źródło: Scott Ambler + Associates (2013).

Diversification of project management methods as a source of competitive advantages

\begin{abstract}
Motivation: The motivation to raise the issue was to draw attention to disadvantages as and advantages of various project management concepts, in particular the group of agile and traditional methodologies within information technology (IT) projects.

Aim: The aim was to demonstrate the statistical profitability of migration to the methodologies better suited for the adaptive industry in which the software-producing enterprises operate. The detailed aim was to show positive dependencies, if the management concept is correctly selected to meet the expectations of the client and the project. Materials and methods: The conclusions were based on a comparative analysis of a group of methodologies, as well as a verification of the research carried out by Scott Ambler + Associates company.

Results: The conclusion was that the traditional approach to project management does not fit into the canon of modern and adaptive techniques, that would meet the requirements set in the era of globalization by flexible IT projects. In addition, the analysis of responses provided by the respondents shows how drastically a change in approach to the entire project cycle affects the probability of success and reduces misunderstandings between client and contractor.
\end{abstract}

Keywords: competitive advantages; management methodologies; risk

JEL: F66; M15; 022 